\title{
Transfer of Amigo wheat powdery mildew resistance gene Pm17 from T1AL-1RS to the T1BL·1RS wheat-rye translocated chromosome
}

\author{
SAI L. K. HSAM*, MARI-CARMEN CERMEÑO, BERND FRIEBE† \& FRIEDRICH J. ZELLER \\ Technische Universität München, Institut für Pflanzenbau und Pflanzenzüchtung, D-85350 Freising-Weihenstephan, \\ Germany and †Department of Plant Pathology, Kansas State University, Manhattan, KS 66506, U.S.A.
}

\begin{abstract}
Powdery mildew resistance gene $P m 17$ located on chromosome arm 1 RS of the T1AL $1 \mathrm{RS}$ translocation in the common wheat cultivar 'Amigo' was transferred to a T1BL-1RS translocated chromosome through selection from a cross with a T1BL· $1 \mathrm{RS}$ cultivar 'Helios'. In addition to gene Pm17, the resistant recombinant derivative designated 'Helami-105' also possesses gene pm5 inherited from cultivar 'Helios'. A-PAGE and SDS-PAGE show that in line 'Helami-105' chromosome 1A is derived from 'Helios' and chromosome arms $1 \mathrm{BL}$ and $1 \mathrm{RS}$ in T1BL-1RS from 'Amigo'.
\end{abstract}

Keywords: powdery mildew, protein electrophoresis, resistance genes, Secale cereale, Triticum aestivum, wheat-rye translocation

\section{Introduction}

Wheat powdery mildew, caused by Erysiphe graminis f. sp. tritici is a widespread disease in temperate climates, occurring worldwide. The common wheat cultivar 'Amigo' carries a T1AL·1RS wheat-rye chromosome translocation (Zeller \& Fuchs, 1983) conferring resistances to wheat powdery mildew (Zeller \& Hsam, 1983) and greenbug (Sebesta \& Wood, 1978; Hollenhorst \& Joppa, 1983). In addition to the wheat-rye translocation, 'Amigo' has the stem rust and leaf rust resistance genes $S r 24$ and $L r 24$ that were derived from Agropyron elongatum (The et al., 1992). Both genes are located on the wheat-Agropyron elongatum chromosome T1BL-1BS-3Ae\# 1L (Jiang et al., 1994).

Wheat cultivars possessing the T1BL-1RS wheat-rye translocated chromosome are more widely distributed in the world (Villareal et al., 1991), and most of these cultivars express the resistance pattern of powdery mildew gene $P m 8$ (Heun \& Fischbeck, 1987). However, powdery mildew resistance gene $P m 8$ derived from 'Petkus' rye in the T1BL-1RS translocated wheat cultivars has already been overcome in Europe (Lutz et al., 1992), hence it is desirable to

\footnotetext{
*Correspondence.
}

introduce a new source of resistance to combat the existing pathogen virulence.

The present study describes the transfer of the resistance gene $\mathrm{Pm} 17$ located on chromosome arm $1 \mathrm{RS}$ of the T1AL-1RS translocation from cv. 'Amigo' (Heun et al., 1990) to the T1BL-1RS translocation. The chromosomal constitution of the recombinant was verified by Giemsa $\mathrm{C}$-banding, isoenzyme and storage protein electrophoreses.

\section{Materials and methods}

The cultivar 'Amigo' was provided by E. E. Sebesta, Oklahoma State University, Stillwater, U.S.A. Wheat cultivar 'Helios' developed by the Breeding Station Schweiger, Moosburg, Germany, carries a T1BL-1RS translocation and possesses powdery mildew resistance genes pm5 and Pm8. About $500 \mathrm{~F}_{2}$ plants from hybrids between cultivars 'Amigo' and 'Helios' were tested against powdery mildew isolates which differentiated $P m 8$ and $P m 17$.

Mildew resistance tests were carried out on segments of primary leaves of plants grown in a phytotron cabinet. The leaf segments were cultured in petri dishes on $6 \mathrm{~g} / \mathrm{L}$ agar and $35 \mathrm{mg} / \mathrm{L}$ benzimidazole. The methods employed for inoculation of the leaf segments 
and disease assessment have been previously described by Zeller et al. (1993).

Plants with the powdery mildew resistance pattern of the cultivar 'Amigo' were screened cytologically and T1BL-1RS translocation homozygotes selected employing the Giemsa C-banding method described by Giraldez et al. (1979). Chromosome pairing behaviour at meiosis between the T1AL·1RS and T1BL-1RS translocation chromosomes in the $\mathrm{F}_{2}$ populations was assessed by the standard Feulgen method.

Gliadin proteins were extracted from seeds using 55 per cent $(\mathrm{v} / \mathrm{v})$ isopropanol, and acidic polyacrylamide electrophoresis (A-PAGE) was conducted using predried gels as described by Hsam et al. (1993). Reduced glutenins were examined by sodium dodecyl sulphate polyacrylamide gel electrophoresis (SDS-PAGE) using 15 per cent predried acrylamide gels according to the procedure described by Westermeier (1993). Glucose phosphate isomerase isoenzymes were studied using the procedure described by Chojecki \& Gale (1982).

\section{Results}

\section{Selection of 'Helami-105', a derivative of 'Helios' $\times$ 'Amigo'}

In the progeny of the $F_{1}$ hybrids between the cultivars 'Helios' and 'Amigo' a total of 469 plants were analysed at the seedling stage for resistance to mildew isolates nos 2,12, 13 and 16. The mildew resistance gene $P m 8$ from 'Helios' showed resistance to isolates nos 2 and 12 , and susceptibilities to isolates nos 13 and 16. Gene $P m 17$ from 'Amigo' is resistant to isolates nos 13 and 16 , but has intermediate response to isolates nos 2 and 12. Seedlings which possessed 'Amigo' resistance were further characterized by Giemsa-C banding for the presence of the T1BL.1RS translocation.

From a total of $469 \mathrm{~F}_{2}$ plants meiotically analysed, more than 70 per cent of the plants possessed quadrivalent chromosome configurations with a mean range of 0.01-1.00 per cell. Among the $F_{2}$ progeny two lines with 'Amigo' resistance and which possessed the homozygous T1BL-1RS translocation were obtained. Further selfing of these lines accompanied by seedling tests for $P m 17$ resulted in the $\mathrm{F}_{6}$ generation of a line designated 'Helami-105'. The response pattern of 'Helami-105' in comparison with the parental lines against eleven differential mildew isolates indicated that this line possessed resistance genes $p m 5$ and $P m 17$ (Table 1).

\section{Identification of the T1BL $\cdot 1 R S$ chromosome by means of Giemsa C-banding, isozymes and prolamin electrophoresis}

'Helami-105' possessed the karyotype of 'Helios' with a T1BL-1RS chromosome. The rye chromosome segment $1 \mathrm{RS}$ was distinguished from chromosomes of wheat by the presence of characteristic large terminal and subterminal C-bands (Fig. 1).

The analysis of group 1 prolamin composition of the two parental cultivars 'Helios' and 'Amigo' together with 'Helami-105' was carried out by acrylamide gel electrophoresis. The secalin bands shown by A-PAGE indicated that the protein subunits of Sec-1 of 'Helami105' showed the same mobility as those of 'Amigo'. 'Helami-105' was characterized by the presence of Gli$A l$ located on 1AS, identical to Gli-Al of 'Helios'; GliAl was absent in 'Amigo' (Fig. 2). SDS-PAGE electrophoresis revealed that 'Amigo' possessed the high-molecular-weight (HMW) protein subunits $2 *$, $7+9,5+10$ and 'Helios' subunits $1,6+8,5+10$. The HMW subunits of 'Helami-105' were $1,7+9,5+10$ indicating that 'Helami-105' inherited the complete $1 \mathrm{~A}$ chromosome pair from 'Helios' and the gene coding for HMW protein subunits on the long arm of $1 \mathrm{~B}$ from 'Amigo'. $\omega$-gliadin encoded by Gli-Bl on $1 \mathrm{BS}$ was not expressed in 'Helami-105' (Fig. 3). The analysis of the

Table 1 Response pattern of 'Helami-105' in comparison with differential reactions of wheat cultivars possessing known powdery mildew resistance genes*

\begin{tabular}{|c|c|c|c|c|c|c|c|c|c|c|c|c|}
\hline \multirow[b]{2}{*}{ Cultivar } & \multicolumn{11}{|c|}{ Powdery mildew isolates } & \multirow{2}{*}{$\begin{array}{l}\text { Resistance } \\
\text { gene }(P m)\end{array}$} \\
\hline & 2 & 5 & 6 & 9 & 10 & 12 & 13 & 14 & 15 & 16 & 17 & \\
\hline 'Selpek' & $\mathrm{s}$ & $\mathbf{s}$ & $\mathrm{s}$ & $\mathbf{s}$ & $\mathrm{r}$ & $\mathbf{s}$ & $\mathbf{s}$ & $\mathbf{r}$ & $\mathrm{s}$ & s & $\mathrm{s}$ & 5 \\
\hline 'Disponent' & $\mathrm{r}$ & s & $s$ & $\mathbf{r}$ & $s$ & $\mathrm{r}$ & $s$ & $\mathbf{s}$ & $s$ & $s$ & $\mathbf{r}$ & 8 \\
\hline 'Helios'† & $\mathbf{r}$ & s & $s$ & $r$ & $\mathrm{r}$ & $\mathbf{r}$ & $\mathbf{s}$ & $r$ & s & $s$ & $r$ & $5+8$ \\
\hline 'Amigo’† & $\mathrm{i}$ & $\mathrm{i}$ & $\mathrm{i}$ & $\mathrm{i}$ & $\mathrm{i}$ & $\mathrm{i}$ & $\mathrm{r}$ & $\mathrm{i}, \mathrm{s}$ & $\mathrm{i}$ & $\mathbf{r}$ & $\mathbf{r}$ & 17 \\
\hline 'Helami-105' & $\mathrm{i}$ & $\mathrm{i}$ & $\mathrm{i}$ & $\mathrm{i}$ & $\mathbf{r}$ & $\mathrm{i}$ & $\mathbf{r}$ & $r$ & $\mathrm{i}$ & $r$ & $r$ & $5+17$ \\
\hline
\end{tabular}

$*_{\mathrm{r}}=$ resistant, $\mathrm{s}=$ susceptible, $\mathrm{i}=$ intermediate.

†Parental cultivars of 'Helami-105'. 
Fig. 1 C-banding karyotype of 'Helami-105' $(2 n=42)$. Arrows point to wheat-rye translocation chromosomes T1BL· 1 RS.
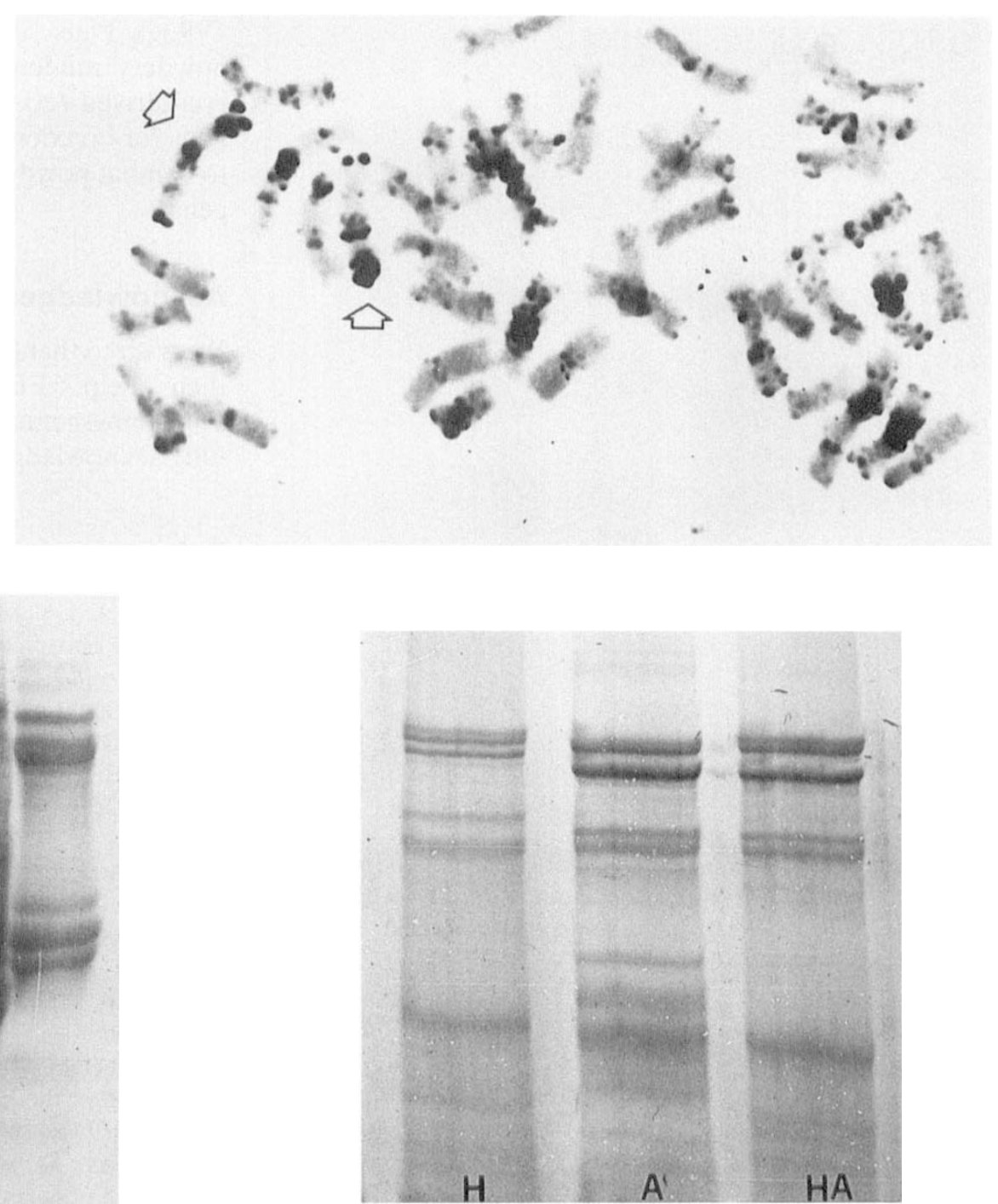

Fig. 3 SDS-PAGE of 'Helami-105' and parental cultivars showing the HMW-bands at the cathodic end. $\omega$-gliadin encoded by chromosome 1BS is detected in 'Amigo'. $\mathrm{A}=$ 'Amigo', $\mathrm{H}=$ ='Helios', $\mathrm{HA}=$ 'Helami-105'.

Fig. 2 A-PAGE electropherogramme of 'Helami-105' and parental cultivars. Solid arrows point to Secalin protein subunits. Bottom arrow points to $\mathrm{Gli}-\mathrm{Al}$ of 'Helios' and 'Helami-105'. Secalin subunits of 'Helami-105' show the same mobility as 'Amigo' and 'Insave' rye and those of 'Helios' show different mobilities. A= 'Amigo', $\mathrm{H}=$ ='Helios', $\mathrm{HA}=$ 'Helami-105', I = 'Insave' rye.

Gpi- isozyme controlled by genes located on the short arm of homoeologous group 1 chromosomes confirmed that 'Helami-105' lacked the glucose phosphate isomerase isozyme gene Gpi-B1 located on 1BS (Fig. 4).

\section{Discussion}

To identify accurately genes which are located on the same arm of a chromosome it is essential to use the proper differential pathogen isolates. In the present study the use of the four mildew isolates nos $2,12,13$ and 16 which were simultaneously inoculated on four leaf segments of the same seedling allows the selection of gene $\mathrm{Pm} 8$ or $\mathrm{Pm} 17$. The disease response pattern of line 'Helami-105' combines the resistance of $\mathrm{PmI7}$ of 'Amigo' and pm5 derived from 'Helios'. The presence of $p m 5$ is corroborated by the response pattern to isolates nos 10 and 14 (Table 1). Cytological evidence clearly shows that line 'Helami-105' possesses a $1 \mathrm{BL} \cdot 1 \mathrm{RS}$ translocation. The $1 \mathrm{BL}$ arm of wheat involved in the translocation expresses the identical carrying the gene coding for HMW glutenin located on HMW glutenin subunits 7+9 of 'Amigo' and not the subunits $6+8$ of 'Helios'. Thus at least a segment 


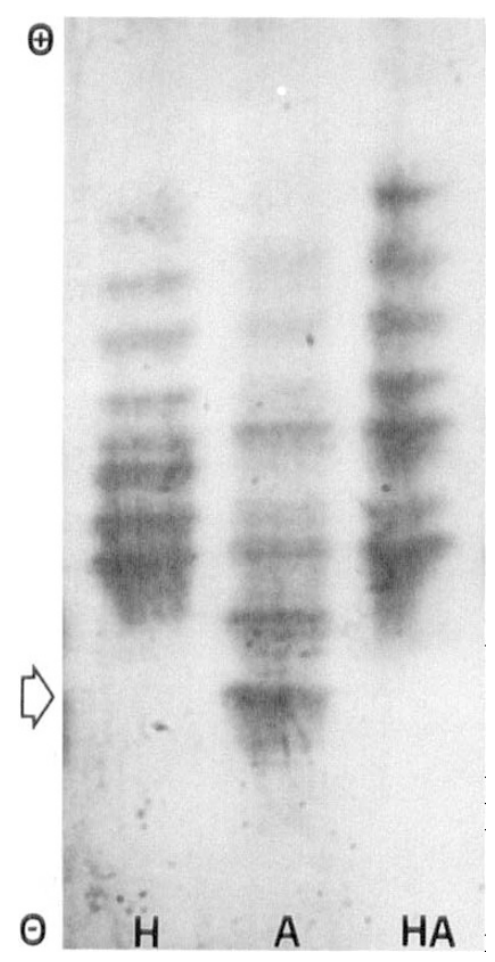

Fig. 4 Grain glucose phosphate isomerase (Gpi) banding pattern of 'Helami-105' and parental cultivars. Arrowhead points to $G p i-B 1$ of 'Amigo'. A= 'Amigo', $\mathrm{H}=$ 'Helios', $\mathrm{HA}=$ 'Helami-105'.

the $1 \mathrm{BL}$ arm of wheat was inherited from 'Amigo'. In addition, the powdery mildew gene $P m 17$ disease response pattern and the secalin protein subunits shown by the mobility in PAGE electropherogramme indicated that the $1 \mathrm{RS}$ segment of line 'Helami-105' is also derived from 'Amigo'.

The high frequency of quadrivalents in meiosis may have arisen from the pairing of the two translocated chromosomes T1BL-1RS and T1AL-1RS, together with the normal 1A chromosome from 'Helios' and the normal 1B chromosome from 'Amigo', giving rise to the presently obtained recombinant with both the $1 \mathrm{BL}$ and 1RS chromosomes from 'Amigo' in the T1BL-1RS of 'Helami-105'. Likewise, the possibility of a wheat-wheat translocation between 'Helios' and 'Amigo' could not be ruled out as Giemsa C-banding at melosis had not been applied.

The breeding of commercial wheat cultivars carrying the T1BL-1RS translocation reported earlier (Zeller \& Hsam, 1983) has now spread worldwide at the hexaploid level (Villareal et al., 1991), and since the first transfer of the T1BL-1RS into 4x-wheat (Friebe $e t$ al., 1987) this translocated chromosome is also gaining importance in breeding programmes at the tetraploid level (Hsam \& Zeller, 1993; William \& Mujeeb-Kazi,
1993). Thus the transfer of 'Insave' rye-derived powdery mildew resistance into the existing 'Petkus' rye-derived resistance cultivars opens up new possibilities for breeders to select for new sources of variation to combat powdery mildew and other pests and pathogens.

\section{Acknowledgements}

We wish to thank Dr. F. Felsenstein and U. Stephan for their help. Financial support by the Deutsche Forschungsgemeinschaft, Bonn (Ze 132/14-1) is gratefully acknowledged.

\section{References}

CHOJECKI, A. J. S. AND GALE, M. D. 1982. Genetic control of glucose phosphate isomerase in wheat and related species. Heredity, 49, 337-347.

FRIEBE, B., ZELLER, F. J. AND KUNZMANN, R. 1987. Transfer of the 1BL/1RS wheat-rye translocation from hexaploid bread wheat to tetraploid durum wheat. Theor. Appl. Genet., 74, 423-425.

GIRALdEZ, R., CERMEÑo, M.-C. AND OREllana, J. 1979. Comparison of $\mathrm{C}$-banding pattern in the chromosomes of inbred lines and open-pollinated varieties of rye, Secale cereale L. Z. PflZücht., 83, 40-48.

HEUN, M. AND FISCHBECK, G. 1987. Identification of wheat powdery mildew resistance genes by analysing host-pathogen interactions. Pl. Breed., 98, 124-129.

HEUN, M., FRIEBE, B. AND BUSHUK, W. 1990. Chromosomal location of the powdery mildew resistance gene of Amigo wheat. Phytopathology, 80, 1129-1133.

HOLLENHORST, M. M. AND JOPPA, L. R. 1983. Chromosomal location of genes for resistance to greenbug in 'Largo' and 'Amigo' wheats. Crop Sci., 23, 91-93.

HSAM, S. L. K., SCHICKLE, H., WESTERMEIER, R. AND ZELLER, F. J. 1993. Identification of cultivars of crop species by polyacrylamide electrophoresis I. Commercial barley (Hordeum vulgare L.) cultivars grown in Germany. Monatsschrift für Brauwissenschaft, 46, 86-94.

HSAM, S. L. K. AND ZELLER, F. J. 1993. Haploid production in durum wheat by the interaction of Aegilops kotschyi cytoplasm and 1BL/1RS chromosomal interchange. Theor. Appl. Genet., 86, 951-954.

JIANG, J., FRIEBE, B. AND GILL, B. S. 1994. Chromosome painting of Amigo wheat. Theor. Appl. Genet., 89, 811-813.

LUTZ, J., LIMPERT, E., BARTOS, P. AND ZELLER, F. J. 1992 . Identification of powdery mildew resistance genes in common wheat (Triticum aestivum L.) I. Czechoslovakian cultivars. Pl. Breed., 108, 33-39.

SEBESTA, E. E. AND WOOD, E. A., Jr. 1978. Transfer of greenbug resistance from rye to wheat with X-rays. Agron. Abstr., 61-62.

THE, T. T., GUPTA, R. B., DYCK, P. L., APPELS, R., HOHMANN, U. AND McINTOSH, R. A. 1992. Characterization of stem rust resistant derivatives of wheat cultivar Amigo. Euphytica, $\mathbf{5 8}, 245-252$.

(c) The Genetical Society of Great Britain, Heredity, 74, 497-501. 
VILLAREAL, R. L., MUJEEB-KAZI, A., RAJARAM, S. AND DEL-TORO, E. 1991. The effects of chromosome $1 B / 1 R$ translocation on the yield potential of certain spring wheats (Triticum aestivum L.) Pl. Breed., 106, 77-81.

WILLIAM, M. D. H. M. AND MUJEEB-KAZI, A. 1993. Rapid detection of $1 \mathrm{~B}, 1 \mathrm{BL} / 1 \mathrm{RS}$ heterozygotes in the development of homozygous $1 \mathrm{BL} / 1 \mathrm{RS}$ translocation stocks of Triticum turgidum $(2 n=4 x=28)$. Genome, 36, 1088-1091.

WESTERMEIER, R. 1993. Electrophoresis in Practice. VCH Verlagsgesellschaft, Weinheim.
ZELLER, F. J. AND HSAM, S. L. K. 1983. Broadening the genetic variability of cultivated wheat by utilizing rye chromatin. In: Proc. 6th Intern. Wheat Genet. Symp., Kyoto, Japan, pp. 161-173.

ZELLER, F. J. AND FUCHS, E. 1983. Cytologie und Krankheitsresistenz einer 1A/1R- und mehrerer 1B/1R-WeizenRoggen-Translokationssorten. Z. PflZücht., 90, 285-296. ZELLER, F. J., J. LUTZ, J. AND STEPHAN, U. 1993. Chromosome location of genes for resistance to powdery mildew in common wheat (Triticum aestivum L.) 1. Mlk and other alleles at the Pm3 locus. Euphytica 68, 223-229. 